\title{
EU REGIONAL POLICY SUPPORT FOR BIOENERGY SECTOR IN POLAND IN 2007-2013 (2015)
}

Joanna RAKOWSKA, Department of European Policy and Marketing, Faculty of Economic Sciences, Warsaw University of Life Sciences, ul. Nowoursynowska 166, 02-787 Warsaw, Poland, e-mail: Joanna_rakowska@sggw.pl (corresponding author) Jarosław Golębiewski, Department of European Policy and Marketing, Faculty of Economic Sciences, Warsaw University of Life Sciences, ul. Nowoursynowska 166, 02-787 Warsaw, Poland, e-mail: jaroslaw_golebiewski@sggw.pl

The EU faces increasing climate, social and economic challenges resulting among others from the negative effects of using fossil fuels. Bioeconomy with its flagship bioenergy sub-sector is meant the key remedy for this situation. That is why the growth of bioenergy production has been promoted and supported in EU financial perspective of 2007-2013 by allocating regional policy funds to strengthen bioenergy sub-sector under operational programs in eligible member states. As Poland has increasing needs to develop bioenergy sector and has been the biggest beneficiary of EU regional policy funds the aim of the paper was to investigate on the main effects of investments in bioenergy sub-sector under operational programmes 2007-2013. The study was based on SIMIK data from the Ministry of Regional Development as of December 31, 2015 and Local Data Bank of the Central Statistical Office of Poland. Qualitative and quantitative analysis show that beneficiaries carried out 80 bioenergy projects of 1442,8 mln PLN total value, including 30,4\% EU cofunding under Operational Programme Infrastructure and Environment and 14 Regional Operational Programmes. These bioenergy investments resulted mainly in construction and modernization of biomass power plants, of which nearly $50 \%$ where agricultural ones as well as in constructing new and expanding already existing biomass-based heating systems in public institutions. Findings show big regional differentiation of the bioenergy investments: from none in mazovieckie (the biggest NUTS 2 in Poland) and opolskie to cumulation of nearly $33 \%$ of bioenergy projects under OPs 2007-2013 in warmińsko-mazurskie. EU co-funding for individual projects ranged from $15 \%$ to $85 \%$, however for nearly half of them it was higher than $45 \%$, conditioning realization of the projects fully. Concluding, EU funding was a significant source of financial support for bioenergy sub-sector in Poland, resulting in developing it especially in warmińsko-mazurskie voivodship.

Keywords: biomass, EU regional policy, Poland, renewable energy.

\section{INTRODUCTION}

Energy is the basic element conditioning our standard of living and technological progress. Unfortunately the facts that it is generated mostly from relatively cheaper fossil fuels increases continuously serious threats to the climate, society and the economy in the European Union and in Poland as its member state as well. Bioeconomy with its flagship bioenergy sub-sector is meant the key remedy for this situation. In the European Commission's approach, bioeconomy covers 'the production of renewable biological resources and the conversion of these resources and waste streams into value added products, such as food, feed, bio-based products and bioenergy', including both traditional and emerging sectors, i.e. 'agriculture, forestry, fisheries, food and pulp and paper production, as well as parts of chemical, biotechnological and energy industries' (EC, 2012). The World Energy Council (2016) defining biomass as all materials of biological origin that are not embedded in geological formations (fossilised), highlights that it can be used in its original form as fuel, or be refined to different kinds of solid, gaseous or liquid biofuels. Furthermore these fuels can be used in all sectors of society, for production of electricity, for transport, for heating and cooling, and for industrial processes.

Bioeconomy is one of the biggest and most important components of the EU economy, and the bio-based economy turnover is estimated at about $€ 2.4$ billion $^{1}$ (Scarlat et al., 2015). The flagship initiative for a resource-efficient Europe under the Europe 2020 strategy supports the shift towards a resource-efficient, low-carbon economy to achieve sustainable growth. Increasing the share of energy from renewable sources is part of a decisive move towards a low-carbon economy (Šturc, 2012). And in practice searching for new renewable sources of energy, capable of replacing fossil fuels, and limiting environmental pollution became one of the most vital actions in this field (Sulewski et al., 2016). The increased use of energy from renewable

\footnotetext{
${ }^{1}$ Including agriculture, food and beverage, agro-industrial products, fisheries and aquaculture, forestry, wood-based industry, biochemical, enzymes, biopharmaceutical, fuels and bioenergy, with almost 22 million persons employed.
}

Copyright (C) 2017 The Authors. Published by Aleksandras Stulginskis University. This is an open-access article distributed under the terms of the Creative Commons Attribution License (CC-BY 4.0), which permits unrestricted use, distribution, and reproduction in any medium, provided the original author and source are credited. 
sources, together with energy savings and increased energy efficiency play a crucial role in promoting the security of energy supply, promoting technological development and innovation and providing opportunities for employment and regional development, especially in rural and isolated areas (Directive 2009/28/EC).

In the above drawn context, biomass as the only indigenous renewable energy resource widely dispersed and naturally occurring, capable of substituting nearly all kinds of fossil fuel energy seems to be the optimal energy source (Klass 1998). European Commission defines biomass as 'biodegradable fraction of products, waste and residues from biological origin from agriculture (including vegetal and animal substances), forestry and related industries including fisheries and aquaculture, as well as the biodegradable fraction of industrial and municipal waste' (Directive 2009/28/EC).

And according to European Commission (EC 2017) biomass represents today more than $60 \%$ of current renewable energy production in the EU 28 - the majority from solid biomass and it is expected that by 2030 the share of biomass will reach around $50 \%$ of overall renewable energy production. The EU's actions aiming at the increase of renewable energy consumption in the total consumption of energy up to $20 \%$ on average, however this share may differ for individual countries. And so for Poland it is 15\% till 2020 (IEO, 2007; URE 2012; Ministry of Economy 2015), and 20\% till 2030 (Ministry of Economy, 2009) Polish national strategic plans and documents (e.g. Ministry of Environment, 2000; Ministry of Economy, 2006; Ministry of Economy, 2009; Minister of Environment, 2010; Minister of Economy, 2010; Ministry of Economy, 2015) incorporate the concept of energy from renewable sources into Polish economic and social development plans and assume its implementation based mainly on wind energy and biomass. Biomass is of key importance in Poland Wójcicki 2012) as it is locally available and has potential to stimulate regional and especially rural development as its production, storage and transport, pre-processing and ultimate use require a considerable amount of labour (Stolarski et al., 2016). Its production dominates in renewable energy production in Poland (Piwowar, 2014; Gołębiewski, 2015; Gołębiewski, 2015a), and may give our country the potential to become EU leader in the production of biogas from agri substrata (Jasiulewicz, Janiszewska, 2012).

Despite all its advantages, in a world of relatively cheap fossil energy, the growth of bioenergy and renewable energy is mainly policy driven, through targets and incentives and as such needs to be promoted and supported especially in member states of lower renewable energy production and lower development level. EU funds allocated within the framework of the EU cohesion policy are the instruments which support the postulate of increasing use of renewable energy sources. The end of the financial perspective of 2007-2013 in 2015, in line with the $n+2$ principle, and the fact that Poland was the biggest beneficiary of EU regional policy funding in this period (EC, 2007), raises the question of the effects of using these resources for supporting biomass projects in both quantitative and qualitative, as well as spatial aspects. The answer to these questions is the main aim of this paper.

\section{RESEARCH METHOD}

The presented analysis was based on the data and programme documents from the Ministry of Infrastructure and Development ${ }^{2}$, especially operational programmes 2007-2013 as well as on the secondary qualitative and quantitative data from SIMIK data base from the Ministry of Infrastructure and Development, as of December 31, 2015. The SIMIK entry for each contract (project) contained, among others, the number and title of contract (project), location of the investment, name of operational programme (OP) and of the priority axis, the profile of the beneficiary, the total value of each project and the value of EU funding for each contract. The content of each entry in SIMIK enabled extracting all projects connected with renewable energy, including biomass projects, out of 106210 projects carried out in Poland under operational programmes 2007-2013 (Rakowska, 2016) and define their type, scope, as well as spatial differentiation. The analysis was also based on information from the Polish Economic Chamber of Renewable Energy, on the data and reports from the Agricultural Market Agency on the number of entities producing agri biogas, data from the Centre of Information on Energy Market and from Energy Regulatory Office. The obtained quantitative data were processed using the classical statistical methods, including Pearson's coefficient and determination index.

\section{FINDINGS}

In 2007-2013 three kinds of operational programs were implemented in Poland: five centrally managed, one multiregional and 16 regional operational programs, 1 in each of the voivodships. EU funding for projects related to renewable energy sources, including biomass, was offered by OP Infrastructure and Environment (OPIE), the biggest operational programme in the history of EU regional policy (Rakowska, Drejerska, 2016) and 16 Regional Operational Programs. As a result, a total of 710 projects (investments) connected with renewable energy sources were carried out in Poland in 2007-2013. Their total value amounted to 7969.20 million PLN, including 34\% (PLN 2688.29 million) of EU funding obtained by the beneficiaries from the Operational Program Infrastructure and Environment and from all 16 Regional Operational Programs (ROP). The remaining $66 \%$ the project total value beneficiaries financed from national funds.

In all of 710 investments in renewable energy sources, $11.3 \%$ were biomass projects. Their total value was close to PLN 1.443 million, including PLN 438 million (i.e. 30.4\%) from EU subsidies. No biomass projects were carried out in two voivodships, i.e. mazowieckie and opolskie, although beneficiaries from these two regions carried out numerous projects related to the acquisition of other types of renewable energy. On the other hand, in the remaining 14 voivodships

\footnotetext{
${ }^{2}$ Previously named the Ministry of Regional Development and also the Ministry of Development.
} 
of the country, beneficiaries carried out a different number of biomass projects with different total values and differentiated EU funding (Figure 1, Table 1).

Warmińsko-mazurskie voivodship is characterized by the highest values of all three discussed features (Figure 1), i.e. the highest number of completed projects (26), their total value and the value of the EU funding (Table 1). Śląskie voivodship presents another case, where only one project on the use of biomass as a renewable energy source was carried out, but it generated the second largest total value of realized projects among the regions and the value of the subsidized region that ranked śląsie as the fifth region in Poland. In regional terms, the number of completed projects is slightly correlated with their total value $\left(\mathrm{r}_{\mathrm{xy}}=0.73\right.$ and $\left.\mathrm{R}^{2}=0.53\right)$ and to significantly with the value of EU co-financing obtained from PO 2007-2013 $\left(\mathrm{r}_{\mathrm{xy}}=0.85\right.$ and $\left.\mathrm{R}^{2}=0.71\right)$.

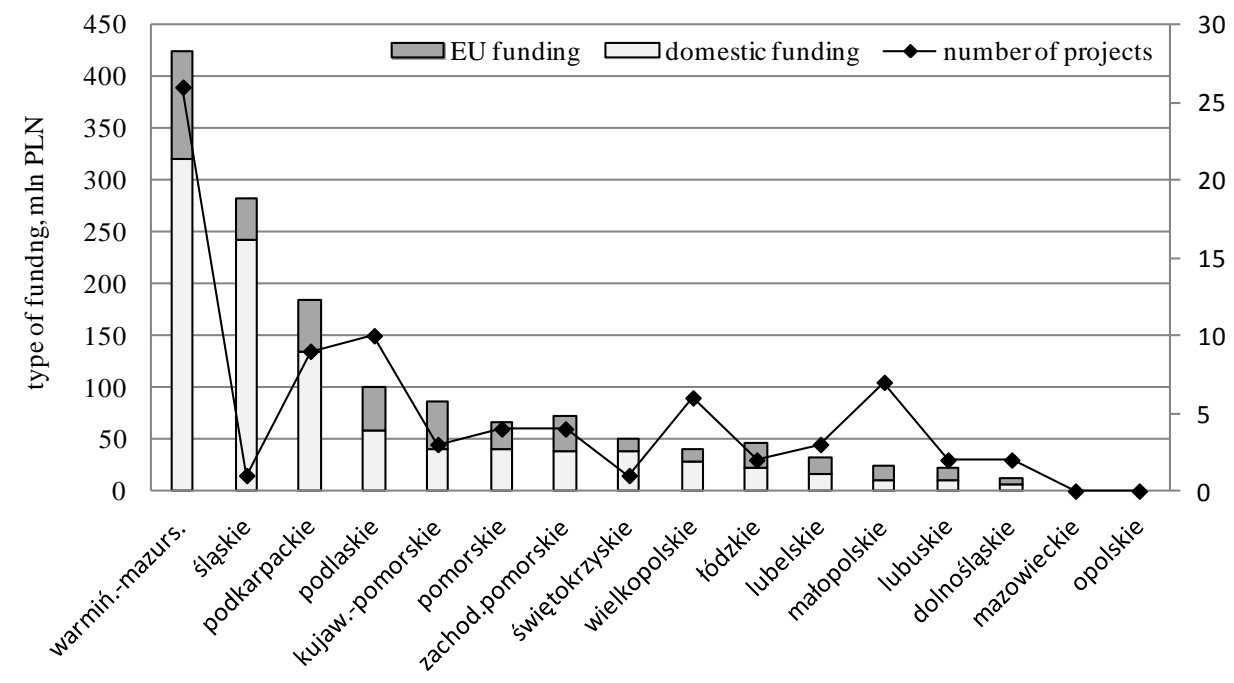

Source: authors' elaboration based on SIMIK data for 2007-2013 (2015).

Figure 1. The number, total value and value of EU co-financing of biomass energy projects carried out under Operational Programmes 2007-2013 in voivodships

EU funds obtained by the beneficiaries for renewable biomass energy projects constituted a very different share in the total value of projects in particular voivodships. It was from just $14 \%$ in śląskie to $58 \%$ in lubuskie (Table 1). This share amounted to nearly $25 \%$ in warmińsko-mazurskie voivodship which stood out in terms of the number of completed projects and their total value. The share of total co-financing in the total value of implemented projects did not approach its upper limit of $85 \%$ eligible costs in operational programs in any of the regions. Considering the value of EU cofinancing in the context of individual projects, it should be emphasized that it is very diverse: from $8 \%$ to $85 \%$, regardless of the implementation region and the program which was the source of EU co-financing.

Table 1. Regional differentiation of investments in renewable sources of energy in 2007-2015

\begin{tabular}{|c|c|c|c|c|c|c|c|}
\hline \multirow{3}{*}{ Voivodship (NTS 2) } & \multicolumn{4}{|c|}{ Biomass projects } & \multicolumn{3}{|c|}{$\begin{array}{l}\text { The share of biomass projects in all renewable } \\
\text { energy projects (REPs) under OPs } 2007-2013(\%)\end{array}$} \\
\hline & \multirow[b]{2}{*}{ A } & B & $\mathrm{C}$ & $\mathrm{D}$ & \multirow{2}{*}{$\begin{array}{l}\text { In total } \\
\text { number of } \\
\text { REPs }\end{array}$} & \multirow{2}{*}{$\begin{array}{l}\text { In total value } \\
\text { of REPs }\end{array}$} & \multirow{2}{*}{$\begin{array}{l}\text { In total EU } \\
\text { funding for } \\
\text { REPs }\end{array}$} \\
\hline & & mln PLN & & $\%$ & & & \\
\hline dolnośląskie & 2 & 11,1 & 5,2 & 46,8 & 11 & 1 & 3 \\
\hline kujawsko-pomorskie & 3 & 86,9 & 46,0 & 52,9 & 21 & 33 & 32 \\
\hline lubelskie & 3 & 32,1 & 16,3 & 50,8 & 3 & 6 & 5 \\
\hline lubuskie & 2 & 21,9 & 12,6 & 57,5 & 14 & 6 & 10 \\
\hline lódzkie & 2 & 46,2 & 23,7 & 51,3 & 6 & 12 & 7 \\
\hline małopolskie & 7 & 24,8 & 14,0 & 56,5 & 7 & 9 & 10 \\
\hline mazowieckie & 0 & 0 & 0 & 0 & - & - & - \\
\hline opolskie & 0 & 0 & 0 & 0 & - & - & - \\
\hline podkarpackie & 9 & 184,9 & 49,9 & 27,0 & 24 & 36 & 31 \\
\hline podlaskie & 10 & 100,7 & 43,1 & 42,8 & 8 & 29 & 26 \\
\hline pomorskie & 4 & 66,1 & 25,3 & 38,3 & 11 & 6 & 10 \\
\hline śląskie & 1 & 282,5 & 40,0 & 14,2 & 6 & 77 & 40 \\
\hline świętokrzyskie & 1 & 49,3 & 12,0 & 24,3 & 20 & 86 & 78 \\
\hline warmińsko-mazurskie & 26 & 424,0 & 104,8 & 24,7 & 25 & 77 & 64 \\
\hline wielkopolskie & 6 & 39,9 & 11,3 & 28,3 & 21 & 9 & 7 \\
\hline zachodniopomorskie & 4 & 72,4 & 33,9 & 46,8 & 11 & 7 & 12 \\
\hline Total & 80 & 1442,8 & 438,1 & 30,4 & 11 & 18 & 16 \\
\hline
\end{tabular}

Explanatory note: A - number of projects; B - total value of projects; C - total value of EU funding obtained from the projects from OP 2007-2013; D

- share of EU co-funding obtained from OP 2007-2013 in total value of the projects.

Source: authors' elaboration based on SIMIK data for 2007-2013 (2015). 
In the total number of projects aimed at acquiring renewable energy (including wind, solar, hydroelectric, geothermal and other kinds) the biomass projects account from $3 \%$ in lubelskie to $25 \%$ in warmińsko-mazurskie. EU funding for biomass projects made from 3\% (in świętokrzyskie) to renewable energy projects (Table 1).

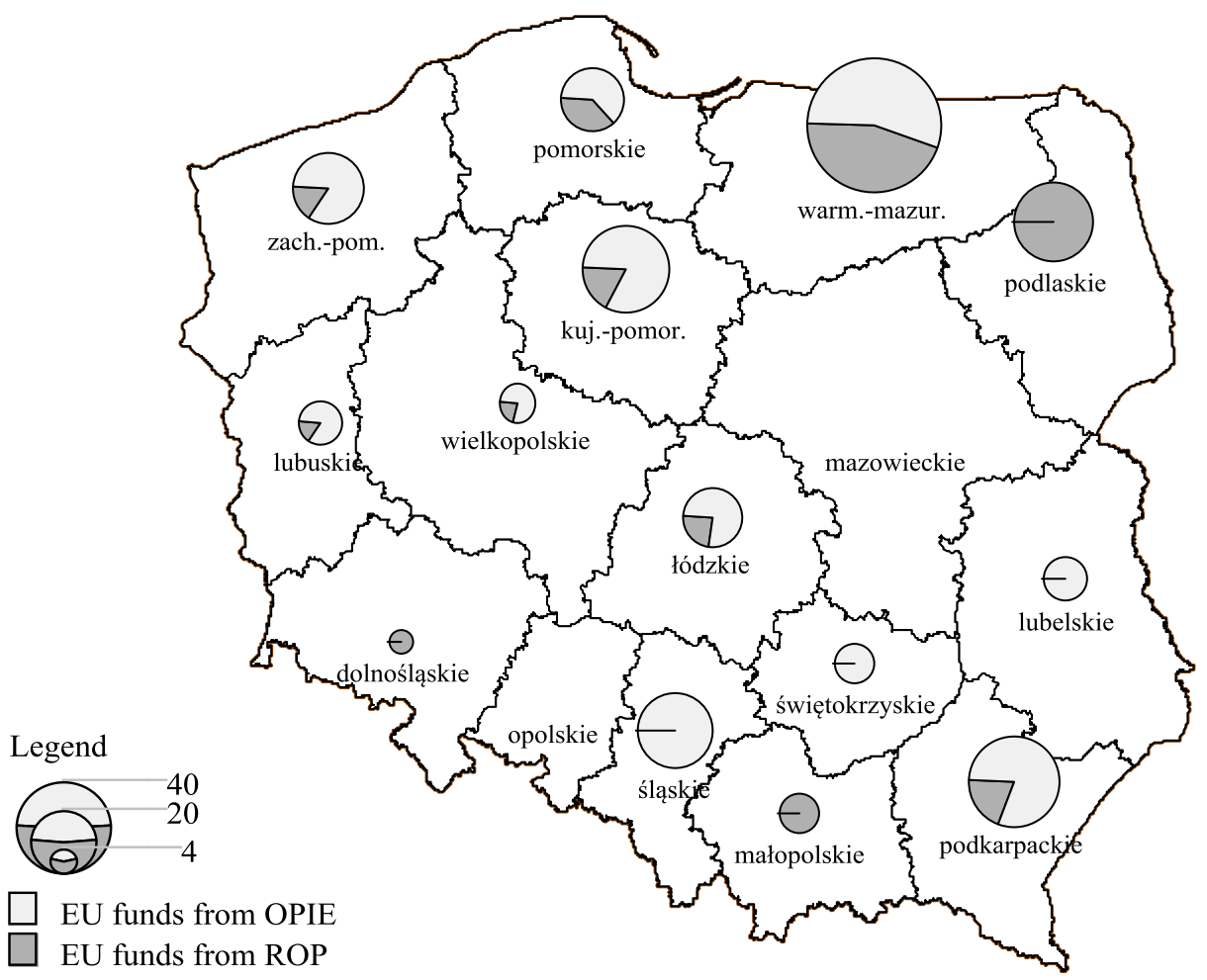

Source: authors' elaboration based on SIMIK data for 2007-2013 (2015).

Figure 2. The value and structure of EU co-financing obtained from Operational Programme Infrastructure and Economy (OPIE) and Regional Operational Programmes (ROPS) 2007-2013 for biomass renewable energy projects in voivodships

Regional Operational Programs 2007-2013 were the main and at the same time the only source of funding for the discussed projects in podlaskie, małopolskie and dolnośląskie. In the remaining voivodships EU funds from OPIE were predominant, and in śląskie, świętokrzyskie and lubelskie it made as much as $100 \%$ of EU funding. In the studied group of 14 voivodships where biomass projects were implemented, there are no significant correlations between the share of EU funding raised from OPIE and from ROPs and the total value of this subsidy $\left(r_{x y}=0.3, R^{2}=0.001\right)$.

The biggest (20\%) share of biomass projects resulted in 16 modernisations of heating systems in public institutions, $19 \%$ of projects resulted in 15 new agricultural biogas plants, $18 \%$ projects contributed to construction of 14 new biogas power plants, $15 \%$ projects resulted in construction of new biogas heating systems in public institutions, effects of $10 \%$ of projects were defined as 'other ways of increasing the use of biomass for energy production', $6 \%$ projects resulted in construction of five biomass boiler houses, $5 \%$ to extending biomass power stations and $4 \%$ to extending biomass boiler houses and also $4 \%$ to extending biomass heating systems.

Such diversified range of renewable energy biomass projects was carried out by different beneficiaries, mostly by enterprises (59\% of projects), but also by municipality (LAU 2) and poviat (LAU 3) self-governments, by the Catholic Church, associations and one university.

Table 2. The number of installations listed in the register of agri biogas producers in 2011-2016

\begin{tabular}{|c|c|c|c|c|c|c|}
\hline \multicolumn{7}{|c|}{ The number of installations listed in the register of agri biogas producers as of: } \\
\hline 01.01 .2011 & 01.01 .2012 & 01.01 .2013 & 01.01 .2014 & 01.01 .2015 & 01.01 .2016 & 01.01 .2017 \\
\hline 8 & 16 & 28 & 42 & 58 & 78 & 94 \\
\hline
\end{tabular}

Source: Agricultural Market Agency (ARR), retrieved from http://www.bip.arr.gov.pl/showdoc.php?inoId=5161, (accessed on 02.11.2017

In 2011-2015 the number of installations listed in the register of agri biogas producers increased from 8 to 78 , i.e. by $975 \%$. However, all 78 installations were built over the analysed 2007-2015 time span. Taking into consideration the fact that EU funding under OPs 2007-2013 contributed to constructing 15 new agricultural biogas plants, it can be concluded that $19.2 \%$ of the installations listed in the register of agri biogas producers were constructed with the support of EU funds.

\section{CONCLUSIONS AND DISCUSSION}

Renewable energy (wind, solar, hydroelectric, ocean energy, geothermal, biomass and biofuels) is an alternative to fossil fuels and contributes to reducing greenhouse gas emissions, diversifying energy supplies, and reducing 
dependence on uncertain and unstable fossil fuel markets (especially oil and gas). EU legislation on the promotion of renewable energy has changed considerably over the recent years. In the currently binding Directive on Renewable Energy, adopted on 23 April 2009 (Directive 2009/28 / EC), it was established that by $202020 \%$ of total EU energy consumption must come from renewable sources. Furthermore, in the transport sector, all Member States are required to achieve a $10 \%$ share of renewable fuels by 2020. The Directive also sets out the various mechanisms that Member States can use to achieve their objectives (support schemes, guarantees of origin, joint projects, cooperation between Member States and third countries) and sustainability criteria for biofuels. In 2007-2013, the EU supported projects in this area within the framework of the Member States entitled to benefit from the EU cohesion policy funds, and Poland was their largest beneficiary.

Qualitative and quantitative analysis show that Polish beneficiaries carried out 80 bioenergy projects of 1442,8 mln PLN total value, including 30.4\% EU co-funding under Operational Programme Infrastructure and Environment and 14 Regional Operational Programmes. These bioenergy investments resulted mainly in construction and modernization of biomass power plants, of which nearly $50 \%$ where agricultural ones, as well as in constructing new and expanding already existing biomass-based heating systems in public institutions. The construction of especially agri biomass power plants stays in line with the assumptions made in government strategic documents (e.g. Ministry of Environment, 2000; Ministry of Economy, 2006; Ministry of Economy, 2009; Minister of Environment, 2010; Minister of Economy, 2010; Ministry of Economy, 2015).

Further findings show big regional differentiation of the bioenergy investments: from none in mazovieckie (the biggest NUTS 2 in Poland) and opolskie to cumulation of nearly 33\% of bioenergy projects under OPs 2007-2013 in warmińsko-mazurskie. The latter case confirms the opinion (Stolarski et al., 2016, p.175) that it is natural for warmińskomazurskie to make the most effective use of biomass of various origins, as the potential for acquisition of such materials in the region is significant.

Financial engineering analysis show that EU co-funding for individual projects ranged from $15 \%$ to $85 \%$, however for nearly half of them it was higher than $45 \%$, conditioning realization of the projects fully. On the other hand, the share of total EU funding absorbed by beneficiaries of individual voivodships in total value of projects carried out by them was lower than $60 \%$.

Concluding, EU funding was a significant source of financial support for bioenergy sub-sector in Poland, resulting in developing it especially in warmińsko-mazurskie voivodship.

\section{REFERENCES}

1. ARR, 2015. The register of agri biogas producers, as of 01.01.2017. Available at: http://www.bip.arr.gov.pl/showdoc.php?inoId=5154 (Accessed on 15.11.2011).

2. Gołębiewski, J., 2015. Bioeconomy in Poland: Condition and potential for development of the biomass market. European Association of Agricultural Economists, 150th Seminar, October 22-23, 2015, Edinburgh, Scotland.

3. Gołębiewski, J., 2015a. Potential of biomass market in Poland (in the context of bioeconomy development). International Scientific Conference "Prices in agri-food sector and its environment', WULS-SGGW, Warsaw.

4. Rakowska J., Drejerska N., 2016: The main environmental effects of Operational Programme Infrastructure and Environment 20072013. Naukovij Visnik Nacional'nogo Universitetu Bioresursiv i Prirodokoristuvannâ Ukraini. Ekonomika, agrarnij menedžment, biznes, Vol. 244, pp. 63-75.

5. Directive 2009/28/EC of the European Parliament and of the Council of 23 April 2009 on the promotion of the use of energy from renewable sources and amending and subsequently repealing Directives 2001/77/EC and 2003/30/EC.

6. EC, 2007. Cohesion policy 2007-2013. Comments and official texts, Office for Official Publications of the European Communities, Brussels.

7. EC, 2012. Bioeconomy Strategy. 'Innovating for Sustainable Growth: A Bioeconomy for Europe'. COM(2012) 60 Final, Brussels, 2012.

8. EC, 2017. Sustainable and optimal use of biomass for energy in the EU beyond 2020. Final Report. VITO, Utrecht University, TU Wien, INFRO, Rütter Soceco, PwC,

9. IEO, 2007. Possibilities of using renewable energy sources in Poland till 2020. The Institute for Renewable Energy, Warszawa.

10. Jasiulewicz, M., Janiszewska, D., 2012. The potential of biomass of Zachodniopomorskie Voivodship in the aspect of using it for energy purposes. Zeszyty Naukowe SGGW w Warszawie: Problemy Rolnictwa Światowego, Vol. 1, pp. 83-93.

11. Klass D.S., 1998. Biomass for Renewable Energy, Fuels, and Chemicals, Academic Press, San Diego.

12. Minister of Economy, 2010. National Renewable Energy Action Plan. Available at http://www.ebbeu.org/legis/ActionPlanDirective2009_28/national_renewable_energy_action_plan_poland_pl.pdf (Accessed on 15.11.2011).

13. Minister of Environment, 2010. National Renewable Energy Action Plan, Warsaw.

14. Ministry of Environment, 2000. Development Strategy for Renewable Energy, available at http://www.pga.org.pl/prawo/strategiaOZE.pdf (accessed on 15.11.2011).

15. Ministry of Economy, 2006. Program for Power Engineering. Available at: http://www.ekoefekt.pl/dokumenty/dokument_13.pdf

16. Ministry of Economy, 2009. Poland's Energy Policy till 2030. Attachment to the resolution of the Council of Ministers no 202/2009 of November 10, 2009, Warszawa.

17. Ministry of Economy, 2010. Development directions for agri biogas plants in Poland in 2010-2020, Warszawa.

18. Ministry of Economy, 2015. National Plan for Developing Low Carbon Economy, project of August 4, 2015, Warszawa. 
19. Piwowar A., 2014. Agricultural biogas plants in Poland - location and technical parameters of the installation. Technika Rolnicza Ogrodnicza Leśna, Vol. 6, pp. 7-9.

20. Polish Economic Chamber of Renewable Energy. Available at http://www.pigeor.pl/, (Accessed on 15.11.2011).

21. Rakowska, J., 2016. Commune self-governments as beneficiaries of EU cohesion policy in 2007-2013 (2015), Wydawnictwo SGGW, Warszawa.

22. Scarlat N., Dallemand J.F., Monforti-Ferrario F., Nita V., 2015. The role of biomass and bioenergy in a future bioeconomy: Policies and facts. Environmental Development, Vol. 15, p. 3-34.https://doi.org/10.1016/j.envdev.2015.03.006

23. Stolarski, M.J., Koniecko, A., Krzyżaniak, M., Przybylski, Ł, Cygan, M., 2016. Renewable Energy in the Warmia and Mazury Region in Poland, (in) Management for Sustainable Development in Rural Areas: at local and regional scales, Bórawski P., Żuchowski I., Szymańska E.J., (eds.), Wydawnictwo Wyższej Szkoły Ekonomiczno-Społecznej w Ostrołęce, Ostrołęka. [In Polish]

24. Šturc, M., 2012. Renewable energy. Analysis of the latest data on energy from renewable sources. Statistics in focus 44/2012.

25. Sulewski P., Majewski E., Wąs A., Szymańska M., Malak-Rawlikowska A., Fraj A., Trząski A., Wiszniewski A., Amrozy M., 2016. Economic and legal conditions and profitability of investments in agricultural biogas plants in Poland. Zagadnienia Ekonomiki Rolnej, Vol. 1(346), pp. 119-143, [In Polish]

26. URE, 2012. Sources of renewable energy. Urząd Regulacji Energetyki. Available at http://www.ure.gov.pl/pl/rynkienergii/energia-elektryczna/odnawialne-zrodla-ener/4762, Odnawialne-Zrodla-Energii.html, (Accessed on 15.11.2011).

27. Wójcicki, Z., 2012. Significance of biomass and other renewable resources of energy. Problems of Agricultural Engineering, PIR 2012 (X-XII), Iss. 4 (78), pp. 5-13. [in Polish]

28. World Energy Council, 2016. World energy resources. Bioenergy. Available at: https://www.worldenergy.org/wpcontent/uploads/2017/03/WEResources_Bioenergy_2016.pdf (Accessed on 15.11.2017). 